\title{
Past and future of sustainable viticulture in Switzerland
}

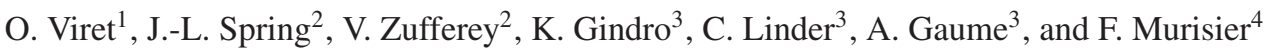 \\ ${ }^{1}$ General Direction of Agriculture, Viticulture and Veterinary Affairs (DGAV), 1110 Morges, Switzerland \\ ${ }^{2}$ Agroscope, 1009 Pully, Switzerland \\ ${ }^{3}$ Agroscope, 1260 Nyon, Switzerland \\ ${ }^{4}$ Rte du tirage, 1806 St. Légier-la-Chiésaz, Switzerland
}

\begin{abstract}
Switzerland is a pioneer country in the development of integrated production (IP) and integrated pest management (IPM). The overall goal is sustainability at the ecological, economic and social level to produce high quality grapes. In 1993, the IP-IPM head-organisation VITISWISS was created. The starting points were the improvement of pest management by the biocontrol of spider mites and the control of grape berry moths by mating disruption and an optimal soil management, followed over the years by state-of-the-art sprayer calibration, development of disease forecasting models (AgroMeteo, VitiMeteo), leaf-area adapted dosage of plant protection products, enhanced biodiversity, water and cover crop management. The efforts and the results gained in a continuous education process by the growers are considerable, but not enough for consumers and politics concerned by the use of plant protection products. The absence of acaricides and insecticides as well as forecasting systems available on the internet (www.agrometeo.ch) for the control of downy and powdery mildew, represent the major progresses. Where mechanisation is possible, herbicides can progressively be replaced by mechanical technics, which is not possible in steep vineyards. The general irrational unscientific trend against "synthetic" plant protection products requests alternatives for the control of fungal diseases and for cover crop management under the vine rows to avoid excessive water-nitrogen competition particularly in the actual context of climate change.
\end{abstract}

\section{Introduction}

Switzerland is a country of $41,285 \mathrm{~km}^{2}$ in central Europe. The landscape is mostly hills and mountains, with a central plateau and large lakes. Agriculture covers approximately $25 \%$ of the surface $(70 \%$ grassland, $27.7 \%$ arable land, $2.3 \%$ perennial crops); $25 \%$ of the country's land is unproductive (permanent snow, rocks, lakes, and glaciers) and $30 \%$ are forests.

Thanks to ecologically aware, pioneer wine farmers and scientists concerned about the environment and the reduction of inputs in viticulture and other crops, the concept of integrated production was created from the seventies on [1-4]. The Federal Research Station Agroscope played a key role in the development of the general concept and methods, including economic and ecological aspects, sustainability and durability, all according to the general guidelines of the International Organization for Biological Control (IOBC) [5]. The impacts of integrated production (IP) or integrated pest management (IPM) for a sustainable viticulture are considerable but consumers and politics expect more in particular regarding the use of plant protection products. The general societal trend against "synthetic" products raises new challenges for viticulture and research to find objective solutions by ensuring high quality grapes for winemaking.

This paper presents the evolution of practices in viticulture in Switzerland from the phytosanitary crises at the end of $19^{\text {th }}$ century to the development and use of plant protection products and the perspectives of a low input sustainable and ecological viticulture under alpine conditions.

\section{Historical backgrounds}

At the end of the $19^{\text {th }}$ century, the successive arrival in Europe and later in Switzerland of powdery mildew (1851), root-phylloxera (1885), downy mildew (1885), rust mite (1900), leaf-gall phylloxera (1908) and grape berry moths (1919) generated the historically known phytosanitary crises, putting winegrowers in desperate situations, reducing dramatically the vine area (Fig. 1), and complicating considerably the cultural practices.

\subsection{End of $19^{\text {th }}$ century to 1950}

\subsubsection{A new constraint: spraying the vines}

Until the fifties, the regular use of sulphur and copper against mildews and the grafting of vines on American rootstocks against phylloxera are generalised and brought serenity in the vineyards. Grape berry moths (Lobesia botrana and Eupoecilia ambiguella) and tortrix (Sparganothis pilleriana) were controlled by highly toxic arsenic salts, progressively replaced by plant extracts such as pyrethrum and nicotine experimented between 1890 and 1910 [6]. Despite the given solution to control pests and diseases, spraying vines with "remedies" became an absolute necessity to ensure yield and quality rendering daily life of winegrowers a lot more fastidious. 


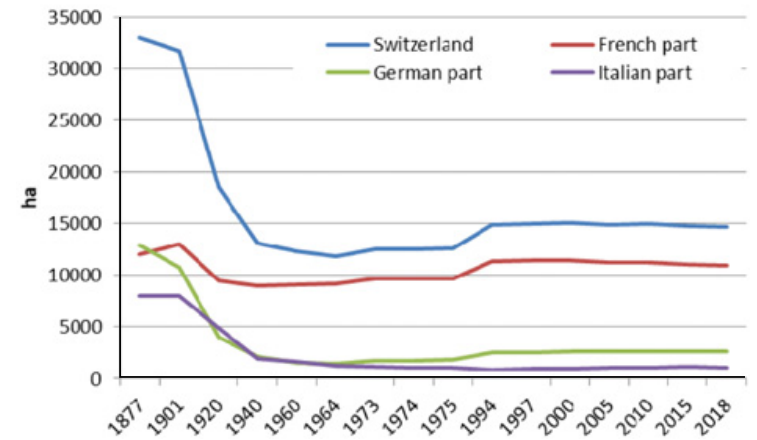

Figure 1. Impact of the phytosanitary crises (end of $19^{\text {th }}$ century) on the viticulture area in the different parts of Switzerland (1877 to 2018).

Table 1. The success of hybrids in France until their prohibition for AOC-Wines in the late fifties.

\begin{tabular}{|c|c|c|c|}
\hline Years & $\begin{array}{c}\text { Total } \\
\text { grapevine } \\
\text { surface (ha) }\end{array}$ & $\begin{array}{c}\text { Surface of } \\
\text { hybrids } \\
\text { (ha) }\end{array}$ & $\%$ \\
\hline 1927 & $1,485,670$ & 216,197 & 14.5 \\
\hline 1947 & $1,550,000$ & 370,000 & 23.8 \\
\hline 1960 & $1,290,000$ & 400,000 & 31.0 \\
\hline 2007 & 835,805 & $6,285^{*}$ & 0.75 \\
\hline
\end{tabular}

* 1000 ha of Baco blanc for Armagnac production.

\subsubsection{Breeding of hybrids to avoid spraying}

A large scale research on resistant grapevine varieties based on other genotypes as Vitis vinifera to avoid completely phytosanitary treatments was initiated. A huge number of interspecific hybrids were breed predominantly in France at the end of the $19^{\text {th }}$ century by crossing $V$. vinifera with resistant Vitis species. In Switzerland, hundreds of such varieties were tested without success because of their poor oenological potential. Only Seibel 1000, Seibel 5455 also called Plantet, and Oberlin 604 were planted for commercial wine production but disappeared rapidly. In France, hybrids had a great success (Table 1) with up to $30 \%$ of the viticulture area until 1960 despite the prohibition of six V. Labrusca cross-cultivars for their foxy note in 1935, and their general revocation from the AOC in 1953.

\subsection{From the fifties until today}

\subsubsection{Soil management and planting density}

In Switzerland all vineyards were planted with high plant densities of 10,000 to 12,000 vines per hectare, each one trellised on a picket (Gobelet) and managed by hand (Fig. 2). The overall work, rises more than 1500 hours per ha per year. Today this cultivation system represents less than $5 \%$ of the growing area. Soil management to control weeds belongs to the most fastidious operation when made by hand. In this context, the first dinitro-orthocresol (DNOC) and triazine herbicides (simazine and atrazine) or 2,4-dichlorophenoxyacetic acid (2,4D), later diquat and paraquat developed in the fifties represented a real revolution for the growers. The general rule was to clean weeds on the whole surface with high erosion risks

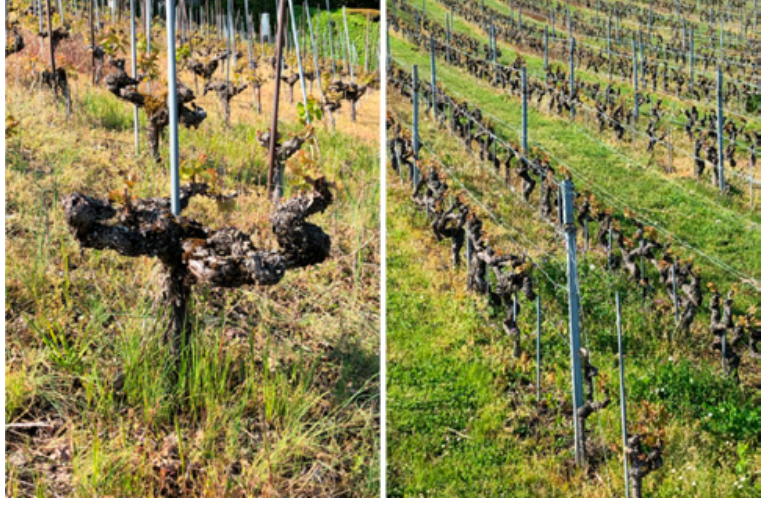

Figure 2. The high density Gobelet system (left) compared to wire-trellised spur-pruned vines with lower plant densities.

on steep vineyards, losses of organic material and upper soil horizons during thunderstorms.

The general change by reducing plant densities $(6,000$ 8,000 plants per ha) planted across the slopes on terraces, Guyot- or spur-pruned and trellised on wires was the second considerable change in managing the vineyards, including the slow development of a light mechanisation. The use of herbicides was reduced to the strip under the vine rows, weeds were grown to prevent erosion and to favour biodiversity of arthropods, and the organic material content increased. Today, these principles are integrally part of IP applied on $95 \%$ of the vineyards.

\subsubsection{Control of pests and mites}

Insecticides and acaricides to control the major pests and mites (Tetranychus urticae and Panonychus ulmi) were regularly sprayed, more and less in accordance with their epidemiology by using for example light traps to attract the butterflies of grape berry moths. Organochlorates (e.g DDT), organophosphates (e.g parathion) and specific acaricides appeared with a large number of active ingredients, all concerned by the resistance of pests and mites as a consequence of their regular and intensive use. In the seventies, the general concern about this situation led to the concept of integrated production (IP) or pest management (IPM), aiming to priories biological control approaches and to spray active ingredient only when all other control measures have been taken. As results, mites were and are still controlled by predatory mites (Phytoseiidae) and grape berry moths by mating disruption using synthetic pheromones in plastic diffusors. These achievements reduced significantly the number of sprays to nearly zero for the control of pests. In Switzerland, the number of active ingredients available from 1950 to 1975 , compared to 2018 drop down of about $88 \%$ for acaricides and of $96 \%$ for insecticides.

The arrival of new pests, such as the spotted-wing drosophila (Drosophila suzukii) or progression of the vine leafhopper (Scaphoideus titanus), vector of the quarantine disease flavescence dorée, brings new challenges for biological control strategies.

\subsubsection{Control of fungal diseases}

The control of fungal diseases remains the key point when cultivating highly sensitive $V$. vinifera. The first 
active ingredients sulphur and copper were the only products against downy and powdery mildew until 1955 when captane came on the market. The development of fungicides in Switzerland is relatively recent with a slow start between the fifties and the seventies with the dithocarbamates (maneb, mancozeb, propineb...), the benzimidazols (benomyl, carbendazime, diethofencarbe) and the dicarboximides to control grey mould (vinchlozoline, iprodione, procymidone). Last two groups were rapidly concerned by the resistance of the pathogens questioning the whole control strategies. From the eighties on, a large number of active ingredients were developed, with specific mode of actions and biochemical target sites, to reduce negative side effects on other organisms and on the environment. All these unisite fungicides are restricted in their use, based on FRAC resistance risks [7].

During the same period and still today, research on organic active compounds, plant extracts, antagonistic bacteria or fungi, stimulator of natural defence mechanisms has been very active. Sulphured clay combined with Equisetum-extracts was the first product still available to control downy and powdery mildews with a part efficacy. In Switzerland, partly working products are recognised in the registration process to fulfil the gap of fungicides available for organic growers. Today's list [8] contains Aureobasidium pullulans and Bacillus subtilis to control grey mould, chito-oligo-saccharides and oligo-galacturonides (COS-OGA), laminarine, fennel oil, potassium bicarbonate and potassium phosphonate against downy and/or powdery mildews.

For a successful control of fungal diseases the choice of the fungicides, spraying in accordance with the epidemiological development of the pathogens, the leaf area adapted dosage [10] and a perfect calibration of the spraying devices depending on the vine canopy are key elements to optimize and reduce as good as possible the use of fungicides. All these points are part of the internet platform www. agrometeo. ch developed since 2000 and collecting weather data from 150 weather stations over the whole country to forecast downy and powdery mildews infection risks, among other tools for insects, phenology [11], grape maturation parameters, etc..

\subsubsection{Breeding a new generation of resistant vines}

A more significant reduction of fungicides used in viticulture can be achieved by improving the natural resistance of the variety. Since 1996, the breeding program of Agroscope has been entirely dedicated to resistance against major fungal diseases, including downy, powdery mildews and Botrytis, by conventional crossings of Vitis vinifera with resistant cultivars of the more recent generation (e.g Bronner, Solaris...). Thousands of seedlings obtained are selected after artificial inoculation of downy mildew, and the surviving ones characterized by their phytoalexins profiles [9]. Ten years of field experiments under different climatic conditions in the vineyards and wine-making with strict evaluation protocols complete the selection process. Today, two crosses of Gamaret (resistant to Botrytis) and Bronner (resistant to mildews) named Divico (red) and Divona (white) are successfully planted in Switzerland and recognised for AOC-wines. In a joint-project with INRA (Institut National de Recherche Agronomique, France) since 2010 on pyramiding genes from different origins to obtain polygenic resistance, breeding lines were combined and will bring new varieties for a more sustainable viticulture in a next future.

\section{Achievements and discussion}

The integrated production (IP) or integrated pest management (IPM) using plant protection products as the last alternative after having taken all biological, ecological and cultural technics to control pests and diseases has play a key role in Switzerland in term of ecological benefits, particularly in the control of arthropods and mites. For example, the control of red mites (P. ulmi) and two spotted mites (T. urticae) until the sixties, requested up to five sprays inducing the spiral of resistance of the mites. It took over twenty years of research on biological control to discover the right naturally predators depending on the regional climatic conditions, to develop simple approaches for their introduction into the vineyards, with the unconditional help of motivated growers. The benefits can still be measured today with the complete absence of acaricides to control these both pests in viticulture. Mating disruption to control grape berry moths is another example of durable success, avoiding spraying of insecticides over more than $75 \%$ of the growing area.

For fungal diseases, to reach a similar result, only resistant varieties can be considered [12]. All V. vinifera grape varieties are sensitive to mildews (Plasmopara viticola and Erysiphe necator) and request spraying at regular intervals to ensure quality yields. The approaches with natural products, the reinforcement of natural defence mechanisms like phytoalexins [13] or the use of biodynamic preparations contribute to partial efficacies and therefore request generally more spraying to control diseases. These compounds are of interest when disease pressure is low or as complement of an IPM spraying schedule. In order to optimise the use of fungicides, the time of spraying, the choice of the active ingredient and the proper application on the target are the key elements of efficacy while reducing the impact for the environment. Application techniques and sprayer calibration, in particular the optimisation of the air flow on air-blast sprayers, seem evident but are the most lacks in practice, leading to diffuse pollution, user's contamination and poor efficacies. To overcome it, the internet platform www.agrometeo.ch allows spraying in accordance with the epidemiology of diseases following the VitiMeteo models [11], calculating the precise dose based on the leaf area via leaf volume of the canopy [10] and calibrating the sprayer after the Caliset-method [14].

Table 2 summarises the impacts and benefits obtained from comparative field experiments over the last decades to reduce the use of plant protection products in viticulture.

\section{Perspectives}

Today's general negative thought about phytosanitary products for environmental and human health reasons has an irrational compound, is fare away from the scientific knowledge and practical realities, and belongs to wishful thinking. In the history of plant protection, such concerns came already out in the eighties when biological control 
Table 2. Results obtained on field experiments in Switzerland over the last decades using different approaches to reduce the use of plant protection products (insecticides, acaricides, fungicides). Impact calculated on an estimated average total number of sprays of 12 per year for European northern vineyards.

\begin{tabular}{|c|c|c|}
\hline Approaches & $\begin{array}{c}\text { Impact } \\
(\boldsymbol{\%})\end{array}$ & $\begin{array}{c}\text { Number of } \\
\text { sprays }(\boldsymbol{N}=\mathbf{1 2})\end{array}$ \\
\hline $\begin{array}{c}\text { Biological control } \\
\text { of mites }\end{array}$ & $\begin{array}{c}-25 \text { to }-30 \\
\text { acaricides }\end{array}$ & -3 to -4 \\
\hline $\begin{array}{c}\text { Mating } \\
\text { disruption }\end{array}$ & $\begin{array}{c}-15 \text { to }-25 \\
\text { insecticides }\end{array}$ & -2 to -3 \\
\hline $\begin{array}{c}\text { Disease forecasting } \\
\text { www . agrometeo.ch }\end{array}$ & $\begin{array}{c}-8 \text { to }-30 \\
\text { fungicides }\end{array}$ & -1 to -4 \\
\hline $\begin{array}{c}\text { Leaf area adapted } \\
\text { dosage of plant } \\
\text { protection products }\end{array}$ & -20 to -30 \\
\hline $\begin{array}{c}\text { Elicitors, alexins, } \\
\text { natural products, } \\
\text { plant extracts ... }\end{array}$ & 0 to +30 & 0 to +4 \\
\hline Organic, biodynamic & 0 to +30 & 0 to +4 \\
\hline Resistant grapevine & -75 to -100 & -9 to -12 \\
\hline
\end{tabular}

strategies were developed [15] and the use of pesticides questioned [16].

Human appeared on earth more than a million of years ago and the small prehistoric populations lived from picking and hunting, consuming what Mother Nature offered them. About ten thousand years ago, agriculture appeared in the Middle-east and humans started to "manipulate" the environment, interacting in the natural cycles. Since humans wanted to use alone the product of their crops, the other herbivorous organisms and pathogens became undesirable. In the actual context of constant population increase (2019: 7.7 billion humans), globalisation, energy consumption and economic maximisation, the need for food increases.

Productive agriculture without phytosanitary products is an impossible equation, as well as the belief that only biological control methods can be applied or that all so-called synthetic products can be abandoned [14]. Based on this statement, IP and IPM with the global objective to use all available biological, biotechnical techniques before spraying phytosanitary products in accordance with the epidemiological development of the pathogens and by considering for each harmful organism tolerance thresholds is the only sustainable way to produce quality grapevine and other crops. Organic or biodynamic viticulture based on copper and sulphur for the control of downy and powdery mildews among other natural preparations correspond more and less to the viticulture practiced until the fifties, before herbicides and specific active compounds appeared. In reality, this viticulture is seen as a salvation for human health and environment but needs more spraying of partly effective compounds, lead to the accumulation of heavy metal in the soil, and request investments for mechanisation or man-power to manage weeds.

\section{References}

[1] V. Delucchi, Parasitis 86, (1987)

[2] M. Baggiolini, Bulletin de la Société Entomologique Suisse 63 (1990)

[3] M. Baggiolini, IOBC Wprs Bulletin 21, 1 (1998)

[4] A, Stäubli, E. Beuret, A. Fossati, F. Murisier, F.X. Paccaud, W. Pfammatter, J.P. Ryser, Revue suisse Vitic. Arboric. Hortic. 18, 2 (1986)

[5] C. Malavolta, E.F. Boller, IOBC Wprs Bulletin 46 (2009)

[6] C. Linder, P. Kehrli, O. Viret, La Vigne 2 (2016)

[7] FRAC, Code List @*2019 (2019)

[8] S. Perren, B. Egger, T. Kuster, E. Holliger, C, Linder, P.-H. Dubuis, C. Bohren, D. Christen, A. Naef, Revue Suisse Vitic. Arboric. Hortic. 51, 1 (2019)

[9] K. Gindro, K.J.-L. Spring, R. Pezet, H. Richter, O. Viret, Vitis. 45, 4 (2006)

[10] W. Siegfried, O. Viret, B. Huber, R. Wohlhauser, Crop. Protection 26 (2007)

[11] G. Bleyer, H.-H. Kassemeyer, M. Breuer, R. Krause, B. Augenstein, O. Viret, P.-H. Dubuis, A.-L. Fabre, B. Bloesch, P. Kehrli, W. Siegfried, A. Naef, G.K. Hill, L. Mattedi, M. Varner, IOBC-WPRS Bulletin 105 (2014)

[12] O. Viret, K. Gindro, La Vigne 1 (2014)

[13] K. Gindro, S. Godard, I. DeGroote, O. Viret, Revue Suisse Vitic. Arboric. Hortic. 39 (2007)

[14] P.-H. Dubuis, C. Bohren, B. Egger, M. Gölles, E. Holliger, P. Kehrli, S. Kuske, T. Kuster, C. Linder, A. Naef, S. Perren, J.-S. Reynard, S. Schaerer, J.-L. Spring, O. Viret, V. Zufferey, Revue suisse Vitic. Arboric. Hortic. 51, 1 (2019)

[15] A. Stäubli, R. Bovey, Revue Suisse d'Agriculture 16, 6 (1984)

[16] C. Quartier, F. Murisier, Agriculture avec ou sans pesticides? (1976) 